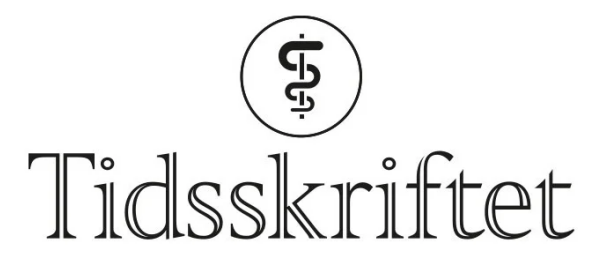

DEN NORSKE LEGEFORENING

\title{
Bør traneksamsyre gis til alle gravide?
}

FRA ANDRE TIDSSKRIFTER

TORBJØRN ØYGARD SKODVIN

Tidsskriftet

\section{Behandling med traneksamsyre ga færre postpartumblødninger i en stor randomisert studie, men den kliniske relevansen er usikker.}

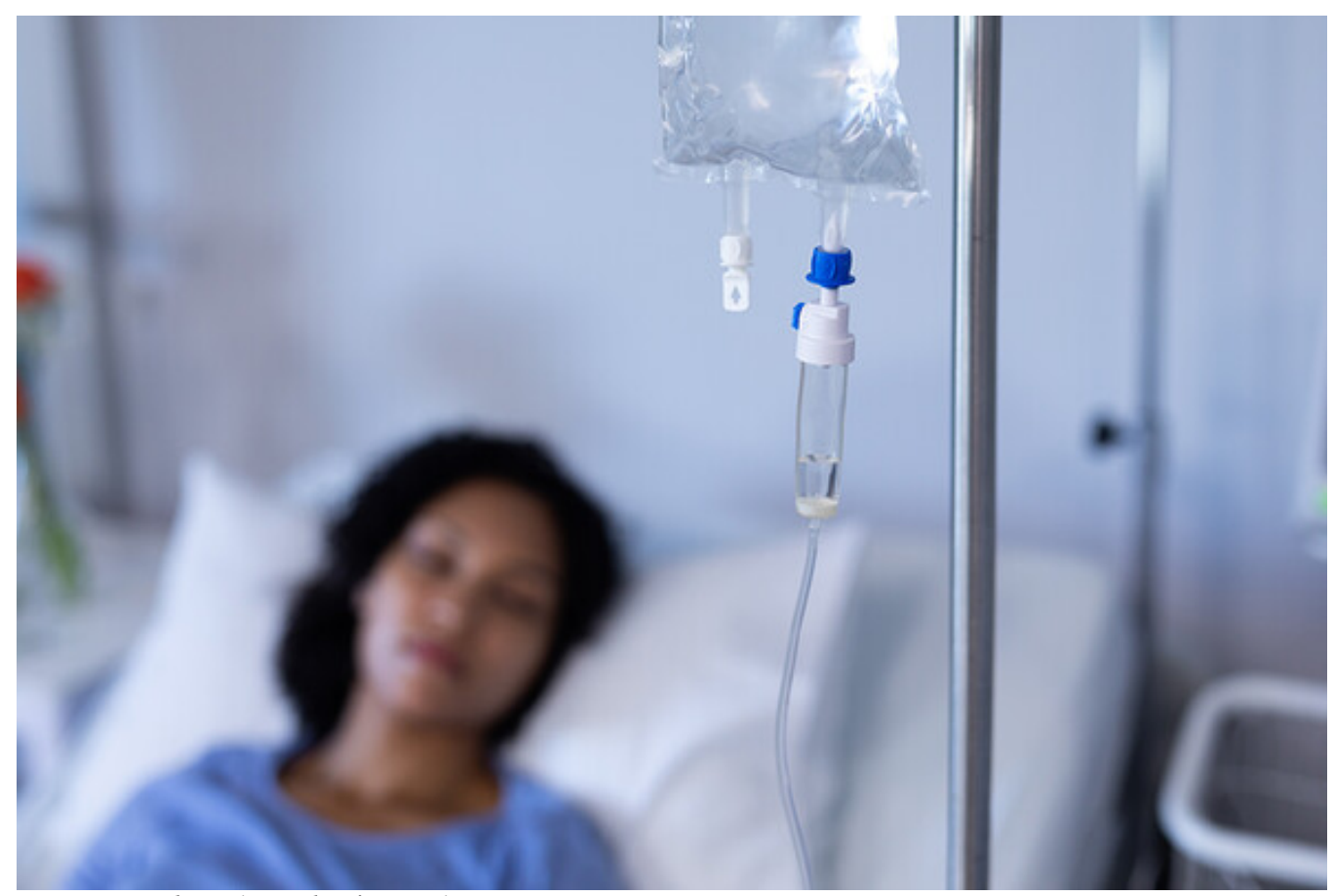

Foto: Wavebreakmedia / iStock

Postpartumblødning er en av de viktigste årsakene til sykelighet etter svangerskap og fødsel. Traneksamsyre er en fibrinolysehemmer som er vist å redusere dødeligheten ved blødninger ved traumer og etter fødsel. Har middelet også en profylaktisk effekt, slik at det bør gis rutinemessig til alle fødende?

I en fransk multisenterstudie av kvinner som skulle gjennomgå keisersnitt, ble rundt 4400 kvinner randomisert til å få enten $1 \mathrm{~g}$ intravenøs traneksamsyre eller placebo like etter at barnet ble forløst (1). Alle kvinnene fikk i tillegg intravenøst oksytocin eller karbetocin, som gir sammentrekning av livmoren. 
Blant kvinnene som fikk traneksamsyre, oppsto postpartumblødning med over 1 liter blodtap hos $27 \%$, mot 32 \% i placebogruppen (justert risikoratio o,84; $95 \%$ KI o,75-0,94). Det var imidlertid ingen statistisk signifikant forskjell hva gjaldt behov for blodtransfusjon eller om helsepersonell vurderte blødningen som klinisk signifikant. Innen tre måneder fikk hhv. o,4 \% og 0,1\% i de to gruppene tromboembolisk sykdom.

- Denne studien er stor og godt gjennomført, men gir ikke grunnlag for å endre norsk praksis, sier Pål Øian, som er tidligere overlege og professor emeritus ved Kvinneklinikken, Universitetssykehuset Nord-Norge.

- Studien omfattet nesten alle kvinner som fikk gjennomført keisersnitt. I Norge anbefaler vi traneksamsyre bare til kvinner med klart $\emptyset \mathrm{kt}$ risiko for stor blødning, og denne studien sier ikke noe spesifikt om denne gruppen, sier Øian.

\section{LITTERATUR}

1. Sentilhes L, Sénat MV, Le Lous M et al. Tranexamic Acid for the Prevention of Blood Loss after Cesarean Delivery. N Engl J Med 2021;384: 1623-34. [PubMed][CrossRef]

Publisert: 14. september 2021. Tidsskr Nor Legeforen. DOI:10.4045/tidsskr.21.0486

(C) Tidsskrift for Den norske legeforening 2023. Lastet ned fra tidsskriftet.no 26. april 2023. 